\title{
Perancangan Tata Kelola Teknologi Informasi di BAPAPSI Pemkab Bandung Menggunakan framework COBIT 5 Pada Domain EDM dan DSS
}

\author{
Rati Amanda Fajrin ${ }^{1)}$, Murahartawaty ${ }^{2)}$, Soni Fajar S. Gumilang ${ }^{3)}$ \\ ${ }^{12) 23)}$ Sitem Informasi, Fakultas Rekayasa Industri, Universitas Telkom \\ Jl. Telekomunikasi Dayeuh Kolot, Bandung \\ 1)ratiamandaf@gmail.com \\ ${ }^{3)}$ sonifajar@gmail.com \\ ${ }^{2)}$ BAPAPSI Pemerintah Kabupaten Bandung \\ Jl. Raya Sorang, Bandung \\ 2) murahartawaty@gmail.com
}

\begin{abstract}
Abstrak - Teknologi informasi memiliki peranan penting untuk mendukung pelaksanaan informasi publik. Pemerintah Kabupaten Bandung memiliki salah satu badan, yaitu BAPAPSI. Permasalahan yang ada di BAPAPSI, terutama pada bidang PPI adalah tidak meratanya jaringan internet di seluruh kecamatan, jaringan internet yang buruk, penanganan insiden yang buruk dan pengadaan server yang tidak mendukung penggunaan aplikasi di BAPAPSI. Oleh karena itu, untuk menyelesaikan masalah yang ada di lingkungan BAPAPSI menggunakan metodologi 7 lifecycle COBIT 5. COBIT 5 menyediakan panduan yang lengkap, pedoman yang komprehensif dalam membantu organisasi untuk mencapai efektivitas penggunaan TI. Tahap pertama pada penelitian ini adalah melakukan penilaian tingkat kapabilitas, kemudian memetakan governance objective, enterprise goals, IT Related Goals dan IT Process pada COBIT 5. Sehingga menghasilkan proses prioritas yaitu EDM04 dan DSS01 yang akan dianalisis dan dilakukan perancangan prosedur tata kelola TI dengan menggunakan COBIT 5. Pada penelitian ini juga merekomendasikan struktur organisasi sasaran sesuai dengan kebutuhan Pemerintah Kabupaten Bandung.
\end{abstract}

Kata Kunci- tata kelola TI, COBIT 5, domain EDM, domain DSS, Pemerintahan

Abstract - Information technology has an important role to support the implementation of public information. Bandung regency government has one of the bodies, named BAPAPSI. The existing problems in BAPAPSI, especially in PPI are uneven internet network in all districts, bad internet connection, bad handling of the incident, and the procurement of servers that do not support the use of the application in BAPAPSI. Therefore, 7 lifecycle COBIT 5 methodology is used to solve the problems in BAPAPSI. COBIT 5 provides complete, comprehensive guidelines in helping organizations to achieve the effective use of IT. The first stage in this research is assess capability level, then the next stage are mapping governance objective, enterprise goals, IT Related Goals and IT Process on COBIT 5. So, the results are the priority process on EDM04 and DSS01 domain to be analyzed and to design procedure IT governance using COBIT 5 . This research also recommends the target of organizational structure in accordance with the needs of the Bandung regency government.

Keywords- IT Governance, COBIT 5, EDM domain, DSS domain, Government

Article history:

Received 27 May 2016; Received in revised form 19 June 2016 \& 29 June 2016; Accepted 29 June 2016;

Available online 28 October 2016

\section{PENDAHULUAN}

Semakin berkembanganya teknologi informasi menuntut perusahaan untuk melakukan pengembangan internal maupun eksternal organisasi. Hal ini mengakibatkan teknologi informasi telah menjadi bagian penting dalam mendukung setiap proses bisnis dan pertumbuhan perusahaan maupun instansi pemerintah. Teknologi informasi juga memainkan peran penting dalam organisasi. Selama bertahun-tahun, TI telah beralih bukan hanya sebagai support melainkan sebagai suatu keharusan di organisasi.
Perkembangan teknologi menjadi hal yang penting dalam mendukung dan menjalankan proses bisnis perusahaan. Akibatnya banyak perusahaan dan para pemimpinnya berusaha untuk menggunakan sebaik-baiknya informasi dalam mendukung keputusan bisnis yang harus dilakukan (Lulu, 2013).

Dewasa ini banyak perusahaan maupun organisasi mulai mengadopsi dan menggunakan prinsip-prinsip dan cara kerja tata kelola TI dalam menjalankan aktivitas organisasi. Konsep tata kelola TI telah menjadi tren dalam sektor publik di berbagai negara (Amali, 2013). 
Pentingnya TI juga menjadi prioritas di sektor publik. Sektor publik melayani masyarakat untuk memberikan strategi layanan yang tepat sasaran dan optimal. Dengan standar tata kelola TI yang baik dapat memberikan transparasi dan pengambilan keputusan yang jelas serta wewenang dan tanggung jawab yang terstruktur. Pemerintahan yang baik adalah yang mementingkan aset publik mencakup tata kelola yang baik pada TI (Carlos, Carlos, \& Isaac, 2014).

Pada penelitian tata kelola TI menggunakan COBIT terdahulu, penelitian yang dilakukan hanya berfokus pada berbagai sektor industri dan perusahaan untuk memeriksa ketercapaian kontrol tujuan yang dianggap paling penting. Namun, seiring perkembangan teknologi, tata kelola TI juga digunakan untuk membantu sektor publik untuk mengukur kontrol dan proses yang telah dilakukan (Omari, Barnes, \& Pitman, 2012).

Penelitian perancangan tata kelola TI dengan menggunakan framework COBIT 5 di pemerintahan telah dilakukan sebelumnya pada sektor publik pada tahun 2015 dengan studi kasus Pemerintah Kabupaten Janeponto. Penelitian yang dilakukan melibatkan responden pejabat terkait di lingkungan organisasi atau SKPD. Tujuan dari penelitian ini adalah meningkatkan optimalisasi aset TI yang dimiliki organisasi dan menilai tingkat kapabilitas saat ini untuk mencapai target tingkat kapabilitas yang telah ditentukan (Maskur, 2015).

Perkembangan Teknologi Informasi dan Komunikasi (TIK), aktivitas kehidupan manusia dalam berbagai sektor tengah mengalami perubahan. Begitu juga pada sektor pelayanan publik yang dilakukan oleh pemerintah. Perkembangan TIK telah melahirkan model pelayanan publik yang dilakukan melalui $e$ government. Pelayanan pemerintah yang birokratis dan terkesan kaku dapat diminimalisir melalui pemanfaatan e-government agar menjadi lebih fleksibel dan lebih berorientasi pada kepuasan pelanggan (Burdefira, 2013).

Pentingnya pengelolaan terhadap TI juga disadari pemerintah Kabupaten Bandung untuk menopang kegiatan pemerintahannya melalui implementasi TI. Dengan standar tata kelola yang baik akan memberikan transparasi dan pengambilan keputusan yang jelas dan wewenang serta tanggung jawab struktur di aset sektor publik. Untuk menunjang kegiatan TI, Kabupaten Bandung memiliki Badan Perpustakaan Arsip dan Pengembangan Sistem Informasi (BAPAPSI) yang merupakan salah satu SKPD di pemerintah Kabupaten Bandung. Tugas dan fungsi BAPASI diatur dalam Peraturan Bupati No. 6/2008 yaitu BAPAPSI sebagai pengelola TIK, pengembangan sistem informasi dan sarana diseminasi informasi publik di Kabupaten Bandung. Dalam menjalankan kegiatannya BAPAPSI memiliki 4 bidang untuk melaksanakan tugas dan tanggung jawab masing-masing. Fokus utama dalam penelitian yang dilakukan adalah pada salah satu bidang yaitu bidang Pengelolaan dan Pengembangan Informasi (PPI) terkait penggunaan TIK. Kepala bidang PPI membawahi 2 sub bidang, salah satunya adalah sub bidang Pengelolaan Sistem Informasi dan Telematika (SITEL) yang terkait pengelolaan TIK dan pengembangan sistem informasi telekomunikasi.

Permasalahan tata kelola TI di BAPAPSI yaitu belum optimalnya TI dalam mendukung jalannya kegiatan operasional dan tujuan pemerintah Kabupaten Bandung. Hal ini dapat dilihat dengan adanya interoperabilitas sistem sehingga data belum terintegrasi, belum memadainya jaringan komunikasi di beberapa kecamatan, penyediaan informasi publik yang belum optimal, jaringan internet dan server yang sering down, respon penanganan insiden yang masih lambat dan sumber daya TIK yang masih terbatas, sehingga teknologi yang diinvestasikan untuk mendukung layanan belum sepenuhnya optimal. Oleh karena itu, untuk meningkatkan optimalisasi sumber daya TI dan mengelola kegiatan operasional di BAPAPSI adalah dengan mewujudkan optimalisasi aset TI yang efektif dan efisien menggunakan COBIT 5.

Dalam mengoptimalisasikan sumber daya TI perlu mengetahui sejauh mana tingkat pengelolaan proses-proses TI di organisasi yaitu dengan pengukuran tingkat kapabilitas. Menetapkan target tingkat kapabilitas dan melakukan gap analisis untuk mendapatkan prioritas perbaikan proses dan aktivitas yang harus dilakukan (Saputra, 2013).

COBIT 5 adalah satu diantara framework IT Governance yang mengusulkan prinsip untuk memandu tata kelola TI. Lima prinsip menekankan pada tujuan dan penciptaan nilai antara para pemangku kepentingan yang berbeda yang mungkin mengharapkan nilai TI yang berbeda pula (George, Aakash, \& Singh, 2014).

Berdasarkan permasalahan tersebut, maka fokus pada peneltian yang dilakukan yaitu domain EDM dan DSS. Fokus penelitian yang dilakukan juga berdasarkan kebutuhan prioritas proses di BAPAPSI dan belum dilakukannya penelitian terkait domain proses EDM dan DSS di BAPAPSI.

Tujuan dari penelitian ini adalah menganalisis dan merancang tata kelola TI menggunakan framework COBIT 5 pada domain EDM dan domain DSS berdasarkan domain proses prioritas kebutuhan di lingkungan BAPAPSI dan merekomendasikan struktur organisasi untuk meningkatkan value business dan value IT bagi instansi pemerintahan. Sedangkan manfaat dari penelitian diharapkan dapat membantu BAPAPSI dalam mengetahui kondisi tata kelola TI saat ini 
dan mengimplementasikan rekomendasi struktur organisasi sasaran, prosedur proses dan dokumen.

\section{Metodologi Penelitian}

Metodologi yang digunakan untuk menyelesaikan permasalahan dalam penelitian menggunakan 7 phases COBIT 5 lifecycle dengan batasan hanya pada 5 tahap yang dilakukan (ISACA, COBIT 5 Implementation, 2012) (ISACA, COBIT 5 Enabling Process, 2012) (ISACA, Process Assessment Model, 2012). Metodologi penelitian yang digunakan dapat dilihat pada Gambar 1.

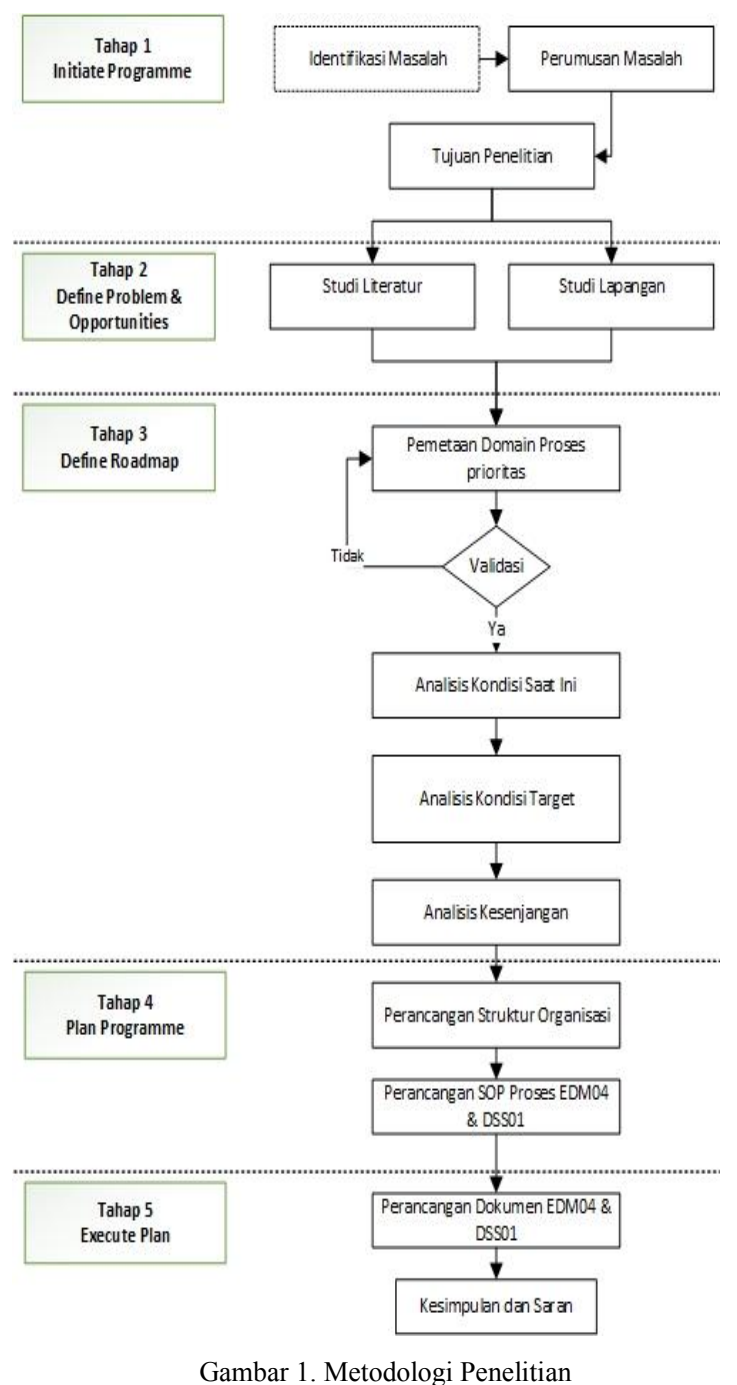

\section{A. Initiate Programme}

Pada tahap initiatie programme dilakukan identifikasi masalah, menentukan tujuan dan menentukan manfaat dari penelitian yang dilakukan.

\section{B. Define Problems \& Opportunities}

Pada tahap define problems and opportunities yang dilakukan adalah mengumpulkan data-data dari studi literatur seperti jurnal, e-book dan skripsi. Sedangkan data-data dari studi lapangan diperoleh dari hasil wawancara dan observasi yang diperoleh dari kepala bidang PPI dan kepala sub bidang SITEL di BAPAPSI.

\section{Define Roadmap}

Pada tahap define roadmap dilakukan proses pengolahan data untuk mendapatkan prioritas domain proses pada EDM04 dan DSS01. Hal pertama yang dilakukan adalah melakukan pemetaan Governance Objective (GO) dengan Enterprise Goals (EG), Enterprise Goals (EG) dengan IT Related Goals (ITRG) dan IT Related Goals (ITRG) dengan IT Process (ITP). Dari hasil pemetaan tersebut menghasilkan IT Process prioritas untuk EDM04 dan DSS01. Selanjutnya, melakukan analisis kondisi saat ini dengan menilai tingkat kapabilitas, analisis kondisi target dan analisis kesenjangan (gap) di BAPAPSI.

\section{Plan Programme}

Pada tahap plan programme dilakukan perancangan berdasarkan framework COBIT 5 dan peraturan terkait pembentukan struktur organisasi TIK. Tahap ini menghasilkan rekomendasi struktur organisasi DISKOMINFO, anggota tim kebijakan TIK dan SOP (Standar Operational Procedure) proses EDM04 dan DS01 untuk direkomendasikan di BAPAPSI.

\section{E. Execute Plan}

Pada tahap execute plan adalah melakukan perancangan dokumen dari SOP (Standar Operational Procedure) proses yang belum lengkap untuk domain proses EDM04 dan DSS01. Selanjutnya tahap ini akan dilakukan penentuan kesimpulan dan saran yang diberikan untuk BAPAPSI dan penelitian selanjutnya.

\section{HASIL DAN PEMBAHASAN}

Berdasarkan metodologi penelitian yang digunakan, maka dilakukan perancangan tata kelola TI untuk proses domain EDM04 dan DSS01 terkait people dan process yang akan direkomendasikan.

\section{A. Hasil Tahap Initiate Programme}

Tahap ini menghasilkan identifikasi masalah berdasarkan kebutuhan organisasi, peluang, instruksi pemerintah dan peraturan terkait serta menghasilkan tujuan dan manfaat dari penelitian yang akan dilakukan. Hasil dari tahap ini digunakan sebagai acuan dalam menjalankan tahap selanjutnya.

\section{B. Hasil Tahap Define Problems \& Opportunitie}

Tahap ini menghasilkan informasi dari studi literatur diantaranya e-book, jurnal dan skripsi terkait tata kelola TI untuk menunjang penelitian khususnya pada domain proses EDM dan DSS. Pada tahap ini juga menghasilkan data dan informasi dari pelaksanaan proses terkait 
pengelolaan TI di BAPAPSI yang digunakan untuk mengetahui prosedur proses yang dilakukan dan tidak dilakukan dalam pengelolaan dan pengembangan TIK.

\section{Hasil Tahap Define Roadmap}

Pada tahap define roadmap menghasilkan pemilihan proses prioritas digunakan untuk mengetahui domain proses yang akan dijadikan fokus penelitian. Untuk mendapatkan proses prioritas dilakukan berdasarkan metode the goals cascade and metrics di COBIT 5 (ISACA, COBIT 5 Implementation, 2012). Hal pertama yang dilakukan adalah melakukan pemetaan Enterprise Goals (EG) dengan Governance Objectives (GO) berdasarkan COBIT 5. Hasil pemetaan tersebut menghasilkan bobot enterprise goals dan dapat dilihat dalam Tabel 1.

TABEl 1. HASIL Bobot ENTERPRISE GOALS

\begin{tabular}{|c|c|c|}
\hline Dimensi BSC & Enterprise Goals & Bobot \\
\hline \multirow{4}{*}{ Finance } & EG1 & 11 \\
\cline { 2 - 3 } & EG2 & 9 \\
\cline { 2 - 3 } & EG3 & 9 \\
\cline { 2 - 3 } & EG4 & 6 \\
\hline \multirow{4}{*}{ Customer } & EG5 & 4 \\
\cline { 2 - 3 } & EG6 & 11 \\
\cline { 2 - 3 } & EG7 & 9 \\
\hline \multirow{4}{*}{ IBP } & EG8 & 4 \\
\cline { 2 - 3 } & EG9 & 5 \\
\cline { 2 - 3 } & EG10 & 11 \\
\hline Learning \& & EG11 & 6 \\
\cline { 2 - 3 } Growth & EG12 & 11 \\
\hline
\end{tabular}

Selanjutnya, dilakukan pemetaan Enterprise Goals (EG) dengan IT Related Goals. Hasil dari bobot pemetaan ini digunakan untuk menghasilkan bobot dari pemetaan IT Process (ITP). Hasil dari bobot IT Related Goals dapat dilihat pada Tabel 2.

TABEL 2. HASIL BoBot IT RELATED GOALS

\begin{tabular}{|c|c|c|}
\hline Dimensi BSC & IT-Related Goals & Bobot \\
\hline \multirow{4}{*}{ Finance } & ITRG1 & 10 \\
\cline { 2 - 3 } & ITRG2 & 5 \\
\cline { 2 - 3 } & ITRG3 & 5 \\
\cline { 2 - 3 } & ITRG4 & 4 \\
\hline \multirow{4}{*}{ Customer } & ITRG5 & 5 \\
\cline { 2 - 3 } & ITRG6 & 9 \\
\hline \multirow{4}{*}{ IBP } & ITRG7 & 6 \\
\cline { 2 - 3 } & ITRG8 & 9 \\
\cline { 2 - 3 } & ITRG9 & 4 \\
\cline { 2 - 3 } & ITRG10 & 7 \\
\cline { 2 - 3 } & ITRG11 & 6 \\
\cline { 2 - 3 } Growth & ITRG12 & 10 \\
\hline \multirow{4}{*}{ Learning $\&$} & ITRG13 & 5 \\
\hline
\end{tabular}

Kemudian, pemilihan domain proses prioritas diakhiri berdasarkan pemetaan IT Related Goals (ITRG) dengan IT Process (ITP) terkait domain EDM dan DSS dengan bobot terbesar yang dihasilkan dari setiap proses EDM dan DSS. Hasil dari bobot ini, akan dijadikan fokus prioritas penelitian perancangan tata kelola TI di BAPAPSI Pemerintah Kabupaten Bandung yaitu dengan bobot 63 pada EDM04 dan bobot 69 untuk DSS01. Hasil dari keseluruhan bobot EDM dan DSS dapat dilihat pada Tabel 3 .

TABEL 3. HASIL BOBOT EDM \& DSS

\begin{tabular}{|c|c|c|}
\hline Domain Proses & Proses & Bobot \\
\hline EVALUATE, & EDM01 & 35 \\
\cline { 2 - 3 } DIRECT AND & EDM02 & 56 \\
\cline { 2 - 3 } MONITOR & EDM03 & 25 \\
\cline { 2 - 3 }$($ EDM) & EDM04 & 63 \\
\cline { 2 - 3 } & EDM05 & 20 \\
\hline \multirow{3}{*}{ DELIVER, } & DSS01 & 69 \\
\cline { 2 - 3 } SERVICE $A N D$ & DSS02 & 41 \\
\cline { 2 - 3 } SUPPORT & DSS03 & 36 \\
\cline { 2 - 3 }$(D S S)$ & DSS04 & 38 \\
\cline { 2 - 3 } & DSS05 & 30 \\
\cline { 2 - 3 } & DSS06 & $\mathbf{5 3}$ \\
\hline
\end{tabular}

Selanjutnya, hasil dari tahap ini adalah analisis kondisi saat ini di BAPAPSI untuk membantu penelitian dalam memastikan kelengkapan proses dan output yang dihasilkan dalam menjalankan kegiatan operasional di organisasi telah dilakukan atau tidak. Proses analisis kondisi saat ini dilakukan dengan menilai tingkat kapabilitas di organisasi terhadap domain proses EDM04 dan DSS01 berdasarkan COBIT (ISACA, COBIT 5 Enabling Process, 2012). Kemudian, menentukan analisis kondisi target berdasarkan target level tingkat kapabilitas yang ingin dicapai. Selanjutnya, untuk mengetahui kesenjangan antara level saat ini dan level target yang ditentukan dihasilkan dari analisis kesenjangan (gap). Tabel 4 menunjukan hasil penilaian tingkat kapabilitas dan hasil analisis kesenjangan (gap) pada EDM04 dan DSS01.

TABEL 4. ASSESSMENT CAPABILITy LeVEL EDM04 \& DSS01

\begin{tabular}{|l|c|c|c|c|}
\hline \multicolumn{1}{|c|}{ Proses } & $\begin{array}{c}\text { Tingkat } \\
\text { Kapabilitas } \\
(\%)\end{array}$ & $\begin{array}{c}\text { Level } \\
\text { Saat } \\
\text { Ini }\end{array}$ & $\begin{array}{c}\text { Level } \\
\text { Target }\end{array}$ & Gap \\
\hline $\begin{array}{l}\text { EDM04 } \\
\begin{array}{l}\text { Ensure } \\
\text { Resource } \\
\text { Optimisation }\end{array}\end{array}$ & $39 \%$ & 1 & 3 & 2 \\
\hline $\begin{array}{l}\text { DSS01 } \\
\text { Manage } \\
\text { Operation }\end{array}$ & $50 \%$ & 1 & 3 & 2 \\
\hline
\end{tabular}

Berdasarkan Tabel 4 dapat diketahui bahwa domain proses EDM04 dan DSS01 berada pada level 1 yaitu Performed Process. Sedangkan level target yang ingin dicapai adalah level 3 yaitu Established Process berdasarkan hasil diskusi dengan kepala bidang PPI dan kepala sub bidang SITEL. Tidak dijalankannya proses dengan lengkap menyebabkan prosedur di setiap proses tidak dihasilkan dengan baik. Nilai kesenjangan 
(gap) yang dihasilkan dari level saat ini ke level target adalah 2 .

\section{Hasil Tahap Plan Programme}

Untuk mencapai tingkat kapabilitas pada level 3 maka, pada tahap plan programme dihasilkan rekomendasi struktur organisasi DISKOMINFO, anggota tim kebijakan TIK dan SOP (Standar Operational Procedure) proses untuk direkomendasikan di BAPAPSI. Dalam merancang struktur organisasi ada beberapa hal yang harus diperhatikan yaitu peraturan-peraturan berikut, diantaranya:

1. Peraturan Menteri Dalam Negeri No. 57 Tahun 2007.

2. Peraturan Presiden No. 41 Tahun 2007.

3. Peraturan Menteri Komunikasi dan Informatika No. 41 Tahun 2007.

Dari peraturan-peraturan tersebut menghasilkan rancangan struktur organisasi sasaran yang akan direkomendasikan.

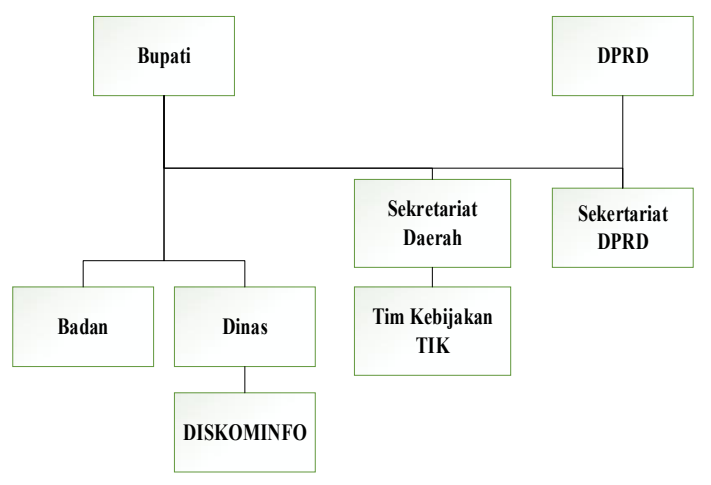

Gambar 2. Struktur Organisasi Pemerintah Kabupaten Bandung

Pentingnya tim kebijakan TIK dalam instansi pemerintah juga dijelaskan dalam Peraturan Menteri Komunikasi dan Informatika. Oleh karena itu, hasil dari tahap ini juga merekomendasikan anggota tim kebijakan TIK.

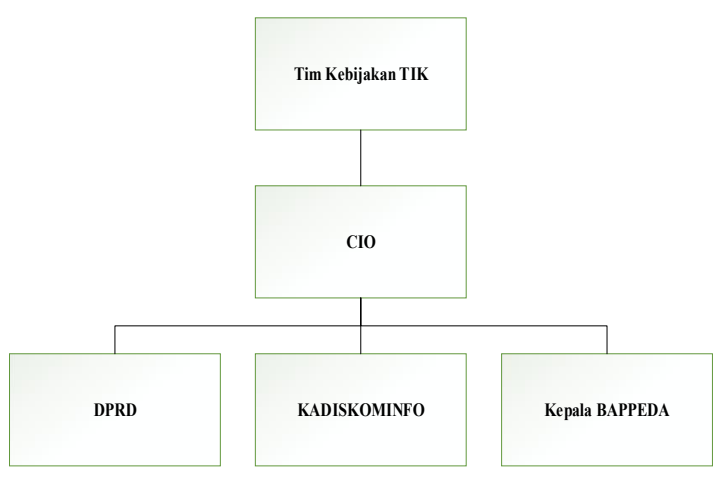

Gambar 3. Anggotza Tim Kebijakan TIK

Berdasarkan Peraturan Menteri Dalam Negeri No. 57 Tahun 2007 mengenai keberadaan Dinas Komunikasi dan Informatika dilakukan peralihan fungsi badan yaitu BAPAPASI khususnya PPI menjadi dinas DISKOMINFO berdasarkan pentingnya TIK dan peraturan terkait di Pemerintah Kabupaten Bandung.

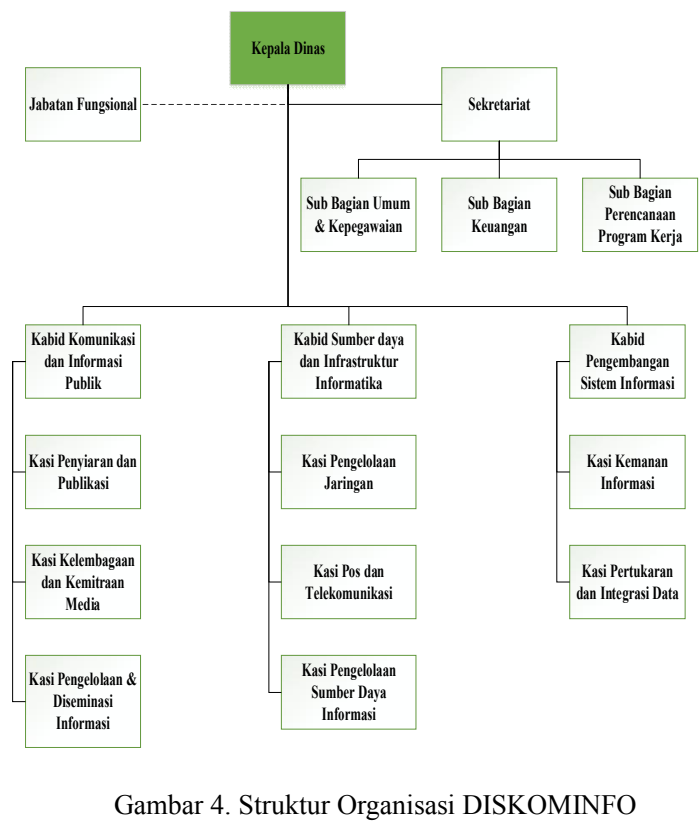

Selanjutnya, pada tahap ini juga menghasilkan perancangan struktur organisasi berdasarkan panduan COBIT 5 dengan memetakan struktur organisasi DISKOMINFO ke dalam struktur organisasi COBIT 5. Pemetaan yang dilakukan dapat mempermudah menentukan pihak yang bertanggung jawab dalam membuat prosedur proses untuk organisasi terkait domain proses di COBIT 5. Gambar 5 menjelaskan pemetaan struktur organisasi COBIT 5 dengan struktur organisasi DISKOMINFO sebagai usulan.

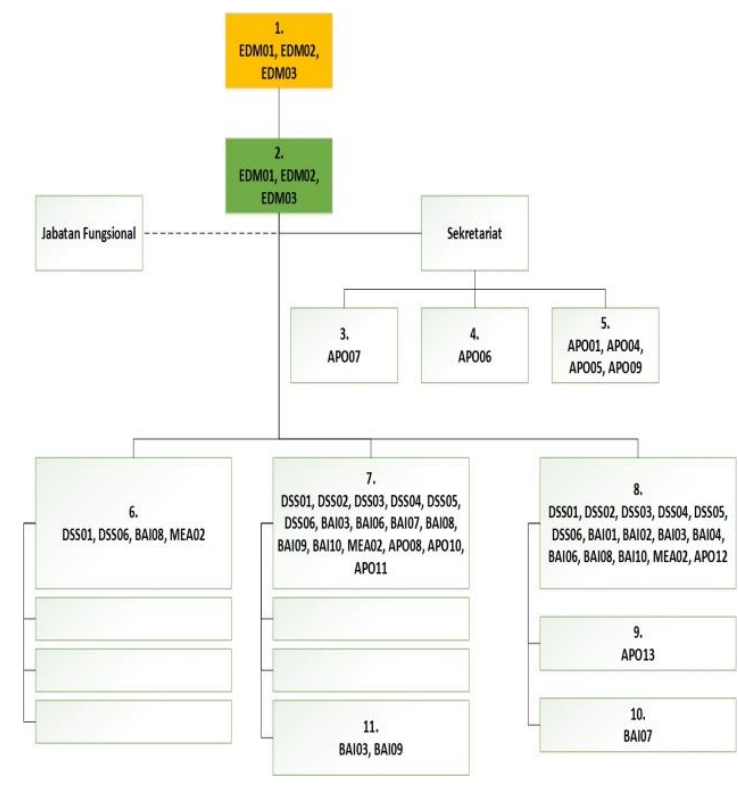

Gambar 5. Pemetaan Struktur Organisasi dengan COBIT 5 
Keterangan:

1. CIO (Chief Information Officer)

2. Kepala Dinas

3. Sub Bagian Umum dan Kepegawaian

4. Sub Bagian Keuangan

5. Sub Bagian Perencanaan Program Kerja

6. Kepala Bidang Komunikasi dan Informasi Publik

7. Kepala Bidang Sumber Daya dan Infrastruktur Informatika

8. Kepala Bidang Pengembangan Sistem Informasi

9. Kepala Seksi Keamanan Informasi

10. Kepala Seksi Pertukaran dan Integrasi Data

11. Kepala Seksi Pengelolaan Sumber Daya Informasi

Struktur organisasi sasaran yang direkomendasikan telah diverifikasi dan di validasi oleh kepala bidang PPI di BAPAPSI untuk diimplementasikan di DISKOMINFO Pemerintah Kabupaten Bandung.

Kemudian, setelah dilakukan perancangan struktur organisasi sasaran, maka proses yang dilakukan selanjutnya akan menghasilkan rancangan prosedur dan proses untuk proses domain EDM04 dan DSS01. Berikut Tabel 5 akan menjelaskan justifikasi proses yang dibutuhkan untuk melengkapi proses yang tidak dijalankan dengan lengkap. Prosedur proses yang tidak dijalankan dengan lengkap diketahui berdasarkan kelengkapan proses yang kurang dari $100 \%$

Tabel 5. Analisis KelengKapan Proses

\begin{tabular}{|l|l|}
\hline \multicolumn{1}{|c|}{ Proses } & \multicolumn{1}{c|}{ Proses Kurang Dari 100\% } \\
\hline EDM04 & EDM04.01 Evaluasi Manajemen \\
Ensure & Sumber Daya \\
$\begin{array}{l}\text { Resource } \\
\text { Optimisation }\end{array}$ & EDM04.02 Mengarahkan Manajemen \\
& Sumber Daya \\
\cline { 2 - 2 } & EDM04.03 Memantau Manajemen \\
& Sumber Daya \\
\hline $\begin{array}{l}\text { DSS01 } \\
\text { Manage } \\
\text { Operation }\end{array}$ & DSS01.01 Melaksanakan Prosedur \\
& Operasional \\
\cline { 2 - 2 } & DSS01.04 Mengelola Lingkungan \\
\cline { 2 - 2 } & DSS01.05 Mengelola Fasilitas \\
\hline
\end{tabular}

Sehingga hasil proses yang dirancang adalah sebanyak 6 SOP proses berdasarkan proses yang tidak mencapai $100 \%$ untuk dapat mencapai level 3. SOP yang dirancang telah di verifikasi dan di validasi oleh kepala sub bidang SITEL di BAPAPSI untuk dapat diimplementasikan di DISKOMINFO Pemerintah Kabupaten Bandung.

\section{E. Hasil Tahap Execute Plan}

Hasil dari tahap execute plan akan dijadikan rekomendasi terkait dokumen yang akan digunakan untuk EDM04 dan DSS01 dalam menjalankan aktivitas proses. Perancangan dokumen dilakukan dengan menganalisis risiko terkait domain proses EDM04 dan DSS01 di BAPAPASI. Analisis risiko dilakukan berdasarkan faktor finansial dan banyaknya frekuensi kejadian risiko. Dari hasil analisis risiko terdapat 7 risiko dengan kategori high dan very high yang akan menghasilkan dokumen perancangan untuk proses EDM04 dan DSS01. Hasil analisis risiko dapat dilihat pada Tabel 6 .

TABEL 6. ANALISIS RISIKO

\begin{tabular}{|c|c|c|c|}
\hline $\begin{array}{l}\text { Sub- } \\
\text { Proses }\end{array}$ & $\begin{array}{c}\text { Skenario } \\
\text { Risiko }\end{array}$ & $\begin{array}{l}\text { Tingkat } \\
\text { Risiko }\end{array}$ & Rekomendasi \\
\hline EDM04.01 & $\begin{array}{l}\text { Tidak ada } \\
\text { panduan alokasi } \\
\text { sumber daya TI }\end{array}$ & High & $\begin{array}{l}\text { Dokumen } \\
\text { guiding } \\
\text { principle for } \\
\text { allocation of } \\
\text { resource and } \\
\text { capabilities }\end{array}$ \\
\hline EDM04.02 & $\begin{array}{l}\text { Tidak ada } \\
\text { komunikasi } \\
\text { yang baik } \\
\text { dengan pihak ke } \\
3\end{array}$ & $\begin{array}{l}\text { Very } \\
\text { High }\end{array}$ & $\begin{array}{l}\text { Dokumen } \\
\text { communication } \\
\text { of resourcing } \\
\text { strategies }\end{array}$ \\
\hline EDM04.03 & $\begin{array}{l}\text { Tidak ada } \\
\text { pemantauan dan } \\
\text { pengukuran } \\
\text { kualitas sumber } \\
\text { daya TI }\end{array}$ & High & $\begin{array}{l}\text { Dokumen } \\
\text { Feedback on } \\
\text { allocation and } \\
\text { effectiveness of } \\
\text { resource and } \\
\text { capabilities }\end{array}$ \\
\hline \multirow[t]{2}{*}{ DSS01.01 } & $\begin{array}{l}\text { Standar } \\
\text { penyelenggaraan } \\
\text { jadwal layanan } \\
\text { belum } \\
\text { ditentukan }\end{array}$ & High & $\begin{array}{l}\text { Dokumen } \\
\text { operation } \\
\text { schedule }\end{array}$ \\
\hline & $\begin{array}{l}\text { Tidak ada } \\
\text { backup log dan } \\
\text { rekaman } \\
\text { kegiatan }\end{array}$ & High & $\begin{array}{l}\text { Dokumen } \\
\text { backup log }\end{array}$ \\
\hline DSS01.04 & $\begin{array}{l}\text { Tidak ada aturan } \\
\text { yang mengatur } \\
\text { penempatan } \\
\text { server yang baik }\end{array}$ & High & $\begin{array}{l}\text { Dokumen } \\
\text { environmental } \\
\text { policies }\end{array}$ \\
\hline \multirow{2}{*}{ DSS01.05 } & $\begin{array}{l}\text { Fasilitas internet } \\
\text { yang sering } \\
\text { down }\end{array}$ & High & $\begin{array}{l}\text { Dokumen } \\
\text { facilities } \\
\text { assessment } \\
\text { reports }\end{array}$ \\
\hline & $\begin{array}{l}\text { Tidak memiliki } \\
\text { sumber daya } \\
\text { cadangan } \\
\text { (geneset) }\end{array}$ & High & $\begin{array}{l}\text { Dokumen } \\
\text { facilities } \\
\text { assessment } \\
\text { reports }\end{array}$ \\
\hline
\end{tabular}

Selanjutnya, dari hasil analisis risiko tersebut menghasilkan rancangan dokumen dari proses yang tidak dijalankan prosedurnya dengan lengkap. Perancangan dokumen yang dirancang telah di verifikasi dan di validasi oleh kepala sub bidang SITEL di BAPAPSI untuk diimplementasikan di DISKOMINFO Pemerintah Kabupaten Bandung

\section{KESIMPULAN DAN SARAN}

Berdasarkan hasil penelitian yang telah dilakukan dalam merancang tata kelola TI terdapat beberapa hal yang harus dilakukan yaitu melakukan penilaian tingkat kapabilitas BAPAPSI untuk mengetahui level kapabilitasnya. Tingkat Kapabilitas BAPAPSI berada pada level 1 dengan katagori Partially Achieved pada EDM04 dan DSS01. Sedangkan untuk mencapai target level 3 akan dilakukan perancangan tata kelola TI dan merekomendasikan BAPAPSI menjadi 
DISKOMINFO Pemerintah Kabupaten Bandung berdasarkan peraturan-peraturan terkait dan pentingnya TI di Pemerintah Kabupaten Bandung. Dengan diterapkannya perancangan tata kelola TI diharapkan dapat meningkatkan efektivitas dan efisiensi penggunaan TI khususnya pada domain proses prioritas EDM04 dan DSS01.

Saran yang dapat diberikan untuk BAPAPSI dan penelitian selanjutnya adalah diharapkan dapat mengimplementasikan penerapan hasil perancangan tata kelola TI guna terciptanya optimalisasi TI di Pemerintah Kabupaten Bandung dan melakukan penelitian untuk semua proses TI yang ada pada COBIT 5 untuk meningkatkan tata kelola TI di Pemerintah Kabupaten Bandung.

\section{DAFTAR PUSTAKA}

Amali, L. N. (2013). Tata Kelola TI yang Efektif di Organisasi Pemerintah Daerah. Seminar Nasional Sistem Informasi (pp. 37-43). Gorontalo: Universitas Negeri Gorontalo.

Burdefira. (2013). Evaluasi Terhadap Implementasi Tata Kelola Teknologi Informasi Berdasarkan Framework COBIT Pada Pemerintah Kota Padang. Skripsi, Universitas Negeri Padang, Program Studi Chief Information Officer.

Carlos, J., Carlos, G., \& Isaac, L. (2014). Implementing Good Governance Principles for The Public Sector in Information Technology Governance Frameworks. Open Journal of Accounting , 3 (1), 9-27.
George, M., Aakash, T., \& Singh, A. (2014). IT Governance Frameworks and COBIT -A Literature Review. Twentieth Americas Conference on Information Systems (pp. 1-10). Savannah: Western Illinois University.

ISACA. (2012). COBIT 5 Enabling Process. USA: ISACA.

ISACA. (2012). COBIT 5 Implementation. USA: ISACA.

ISACA. (2012). Process Assessment Model. USA: ISACA.

Lulu, Y. D. (2013). Analisa Teori IT Governance Menggunakan COBIT 5. Jurnal Teknik Elektro dan Komputer , 1 (1), 99-106.

Maskur. (2015). Perancangan Tata Kelola TI dengan menggunakan Framework COBIT 5 (Studi Kasus: Pemerintah Kab. Jeneponto). Skripsi, Universitas Gadjah Mada, Program Studi S2 Teknik Elektro.

Omari, L. A., Barnes, P., \& Pitman, G. (2012). Optimising COBIT 5 for IT Governance: Examples from the Public Sector. International Conference on Applied and Theoretical Information Systems Research (pp. 1-13). Taipei, Taiwan: Queensland University of Technology.

Saputra, I. N. (2013). Pengukuran Tingkat Kapabilitas dan Perbaikan Tata Kelola Teknologi Informasi Berdasarkan Kerangka Kerja COBIT 5 dan ITIL V3 2011: Studi Kasus PT. XYZ. Skripsi, Universitas Indonesia, Program Studi Magister Teknologi Informasi. 